\title{
Government Expenditure on Education: A Study of Centre and States in India
}

\author{
Babita Balodi ${ }^{1}$ and Aarti Srivastava ${ }^{2}$
}

${ }^{1}$ Research Scholar at National Institute of Educational Planning and Administration (NIEPA), New Delhi, India

${ }^{2}$ Professor, Department of Higher \& Professional Education at National Institute of Educational Planning and Administration (NIEPA), New Delhi, India

Corresponding author: aartijnu@gmail.com

Received: $17-09-2021$

Revised: 21-11-2021

Accepted: 04-12-2021

\begin{abstract}
Since the Global Recession which originated in US and, had its impact on the countries across globe including India, there is a growing tendency of the governments to cut back public expenditure. This phenomenon is referred to as "shrinking state". The present paper discusses the trends in the public expenditure on education at various educational levels. It tries to determine the link between expenditure on education by the States and Centre and their respective GDP. The findings of the paper suggests that there is a negative correlation between the expenditure on education by the State and the respective state gross domestic product (SGDP) at nominal price whereas in case of gross domestic product (GDP) and total expenditure on education in India there is no such relationship. Moreover, the total budgetary provision on expenditure on education is declining although the total budgetary outlay of the Union Government is increasing in absolute terms.
\end{abstract}

Keywords: Government Expenditure, Education, Shrinking State, GDP, SGDP

Government is the important source of finance in the Indian education system. The spending of both the Centre and State constitutes the major part of the total expenditure in India other than the funding from corporate sector in the form of corporate social responsibility, foreign aid. However, after independence the States were given prime responsibility of expansion of education, as education as a subject was placed under state list and thus states had exclusive responsibility and authority. Later on, due to the constitutional amendment of 1976, education subject was transferred to the Concurrent List making the intervention by State and Centre obligatory in this sector.

The public expenditure on education in India is broadly divided into revenue and capital expenditure which is further fragmented into the plan and non-plan expenditure. Revenue expenditure is the expenditure on the recurring expenses in education such as salaries, maintenance of infrastructure etc. Capital expenditure on the other hand, is also called as development expenditure as it is done for developmental purposes such as establishing new schools, colleges in the country. Moreover, each expenditure i.e. capital and revenue is divided into plan and non-plan expenditure. Plan expenditure is the pre-determined expenditure on various educational programmes and provisions. Whereas the non- plan expenditure is of routine nature, done for maintenance and operating purposes. However, the lately the government has altogether removed the distinction between the plan and non-plan expenditure.

How to cite this article: Balodi, B. and Srivastava, A. (2021) Government Expenditure on Education: A study of Centre and States in India. Educational Quest: An Int. J. Edu. Appl. Soc. Sci., 12(03): 227-237. Source of Support: None; Conflict of Interest: None की 
Since the Great Recession there is a growing tendency of the governments to cut back public expenditure. The government across countries is narrowing down public sector with its strategic disinvestment and reduced public spending. The erosion of the state as an institution can be seen in cuts to social programmes and public sector jobs, underfunded infrastructure, the sale of public assets and other forms of privatization, along with the more general weakening of regulatory authority and diversion of resources to the private sector. (Linda Lobao, 2018). This removal of finances, services and staff as well as the failure to increase these resources to match growing need is referred to as retrenchment or state retreat and causing shrinking of state's role drastically. In India the phenomenon of shrinking state is quite evident with government cuts across various sector and its continuous efforts to keep its fiscal deficit within the pre-determined limits mentioned in the budget. This poses important question if India which is at the crucial stage of demographic dividend will be able to afford the reduced government support in terms of public spending in education?

\section{Rationale behind government expenditure on education}

The discourse whether education is a public or a private good has been going on since long time with many international organizations such as United Nation referring education as a public good. Education at least at elementary level has been regarded as a public good. On the other hand, higher education has been characterized as a merit good. Public good has two important characteristics. First, it is non-rivalrous in consumption i.e. consumption of a good by an individual doesn't diminish the consumption of the same good by others. Second, it is non- excludable in nature. Nonexcludability of a good refers to the impossibility or difficulty in restricting the consumption of a good to particular individuals. Goods having these properties are enjoyed by all and are not subject to market competition. The important question which arises is what makes education a public good. If the theory of public good is applied narrowly on education, it could be considered as a private good since it classroom access to individuals can be made exclusive to few individuals by setting higher fee and at the same time, large number of students in a class may hamper the quality of education, thus making it rivalrous. However, in most of the developing as well as developed countries, there is substantial role of the state in providing access and availability of education for free at least at elementary level which exhibit the characteristics of non-rivalrous and non-excludable. Moreover, the state's intervention in education has been further justified due to issues of human rights and social justice.

Nonetheless, this collective consensus around the nature of education as a public good, calls for states active role in order to address the inefficiencies which may arise due to the inherent feature of economic inefficiency or market failure of a public good. Market failure necessitates intervention by state as the market fails to guarantee the optimal provision and price of public good efficiently. Moreover, in a developing country with low percapita income and high inequalities in income and wealth, the state's role in education becomes all more important.

\section{Research Methodology}

The objective of the present study is to analyze the expenditure on education by Centre and States and to further investigate the link between the expenditure on education and the respective GDP at Union and States level. The study is based on the secondary data from Ministry of Education and finance which is analyzed through appropriate statistical and econometrics tools.

\section{Hypothesis of the study}

H0: there is no correlation between the Expenditure on Education and Gross Domestic Product (GDP) in India.

H0: there is no correlation between the Expenditure on Education and State Gross Domestic Product (SGDP) in India.

\section{Analysis of Data}

It is evident from the Fig. 1 that the expenditure on education (centre and states) as a percentage of GDP (nominal) is between 3 to 4 over the period of last fifteen years. It has fallen continuously for the five 


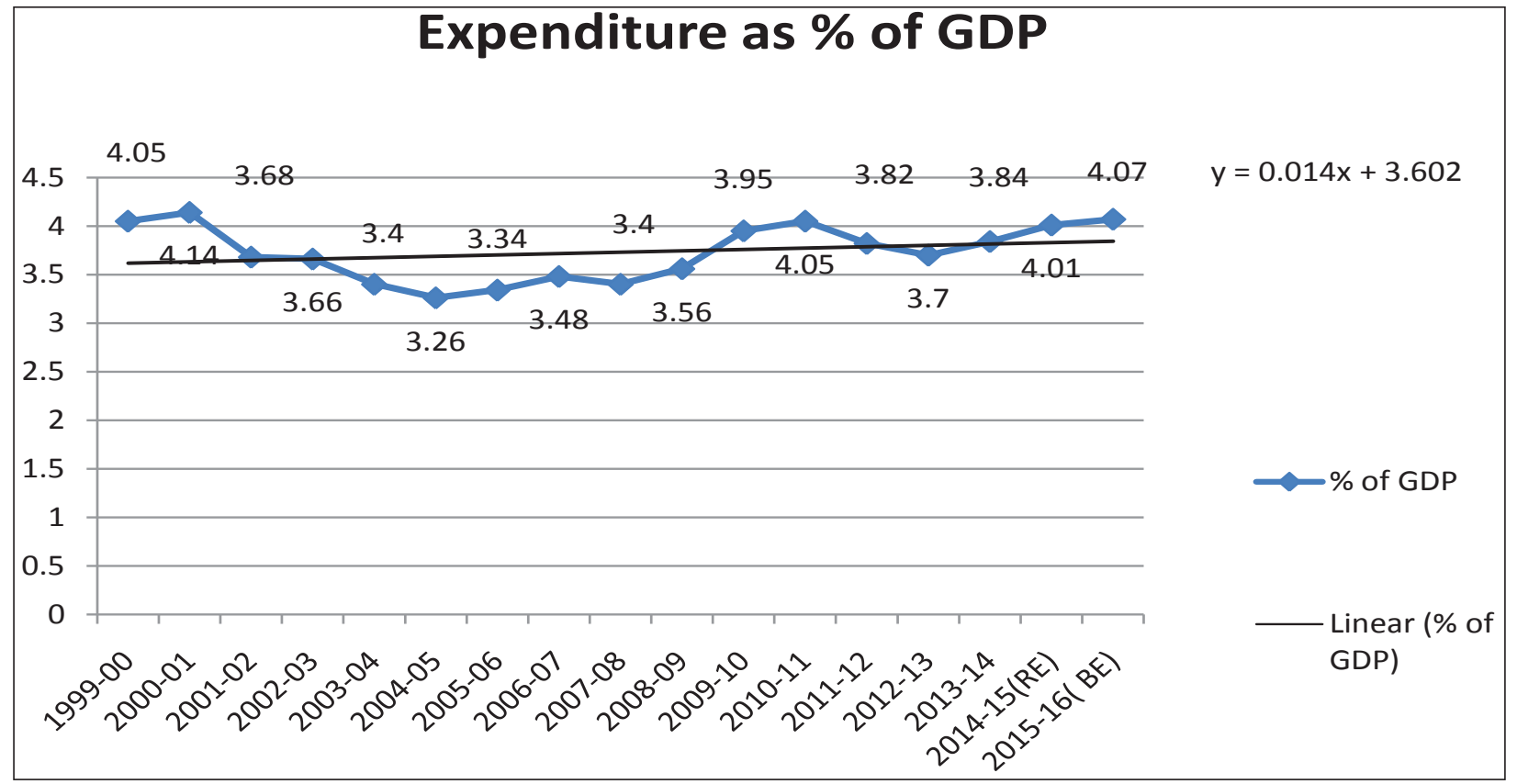

Source: Analysis of Budgeted Expenditure on Education 2013-14 to 2015-16.

Fig. 1: Total Expenditure on education as a percentage of GDP in India

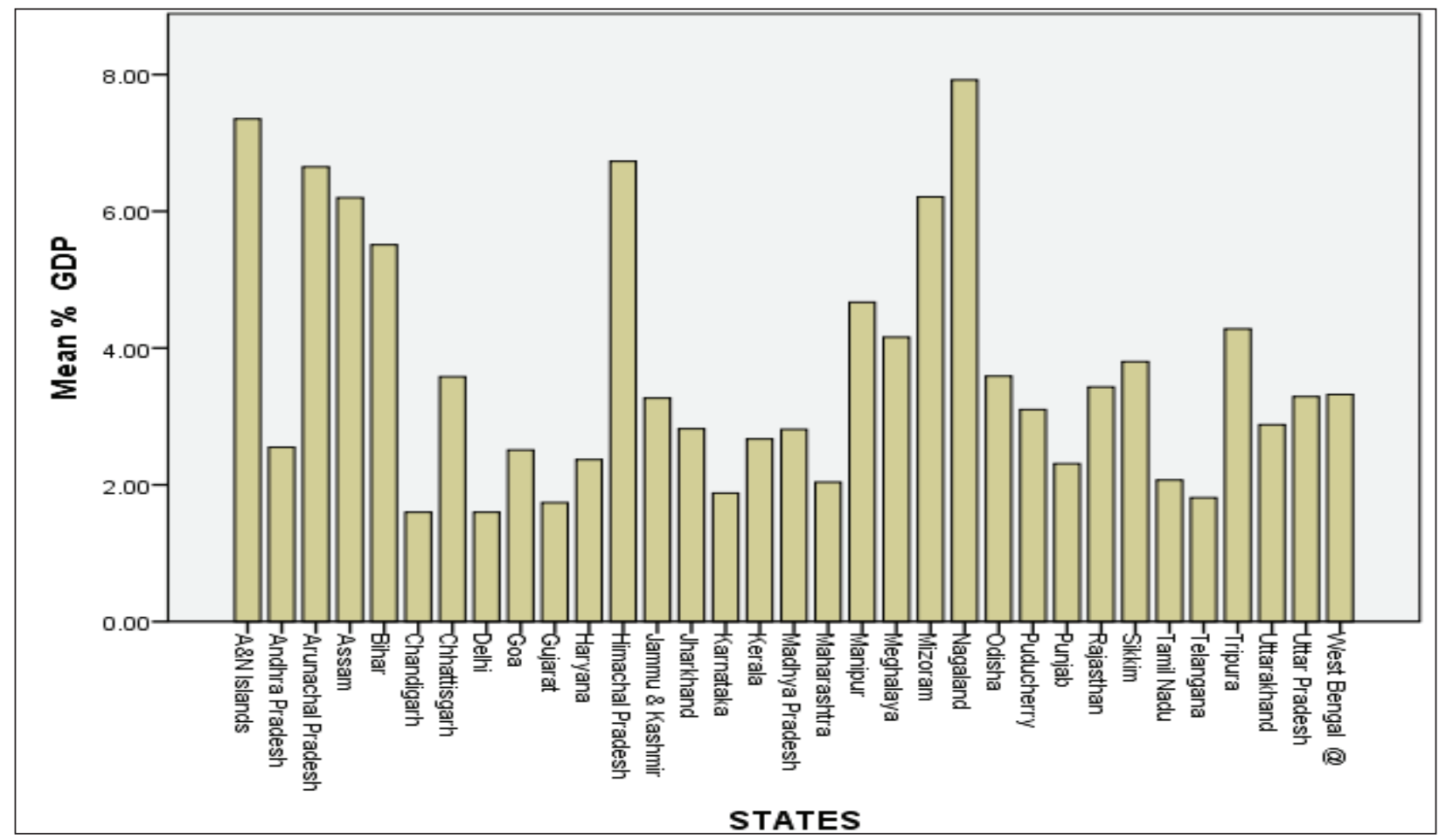

Source: Analysis of Budgeted Expenditure on Education 2013-14 to 2015-16.

Fig. 2: Total Expenditure on Education by States as a percentage of GDP

years period starting from 2000 at $4.14 \%$ to $3.26 \%$ in 2005. Since then it took a steady start with meager ups and down reaching its peak in 2015-16 where it is estimated at 4.07 .
The Fig. 2 shows that there is lot of variation when it comes to percentage of GDP spent on education among Indian states and UTs. Gujrat which is the second largest state in terms of SGDP spent only 
$1.74 \%$ on education, whereas Nagaland spent the highest around $7.4 \%$ much higher than the national estimate expenditure of $4.7 \%$ of the GDP. Moreover, almost every north eastern state of India is spending around $4 \%$ and above on education whereas rest of the Indian states are spending less that the national estimated spending except Bihar and Himanchal Pradesh.

In Fig. 3 shows the revenue expenditure of various states in the year 2015-16. Uttarakhand has the higher revenue expenditure followed by Maharashtra and Rajasthan. Smaller states such as Goa, Manipur, Mizoram, Nagaland etc. have the lowest revenue expenditure despite having high share of expenditure as a percentage of SGDP on education.

The Fig. 4 shows the share of elementary education in the total expenditure on education is highest which is followed by secondary education, higher education and university and technical education.

Despite of shredding away highest share, the expenditure on elementary education has drastically fallen from 2006-07 to 2015-16. It has fallen continuously from 2006-07 till 2010-11, its lowest point. However, since 2010-11 it rose till 2014-15 and finally decreasing.

The share of secondary education in the total expenditure has been rotating around 28 to 30 percentage. In 2006-07, it was 28.76 percent and then rose to 31 percent till the year 2010-11 and then started falling.

Higher education received the second lowest share in the total expenditure on higher education. In 2006-07, it was just 10.88 percent but it increased since then reaching to 12.84 percent in the year 2015-16 despite taking a deep plunge in the year

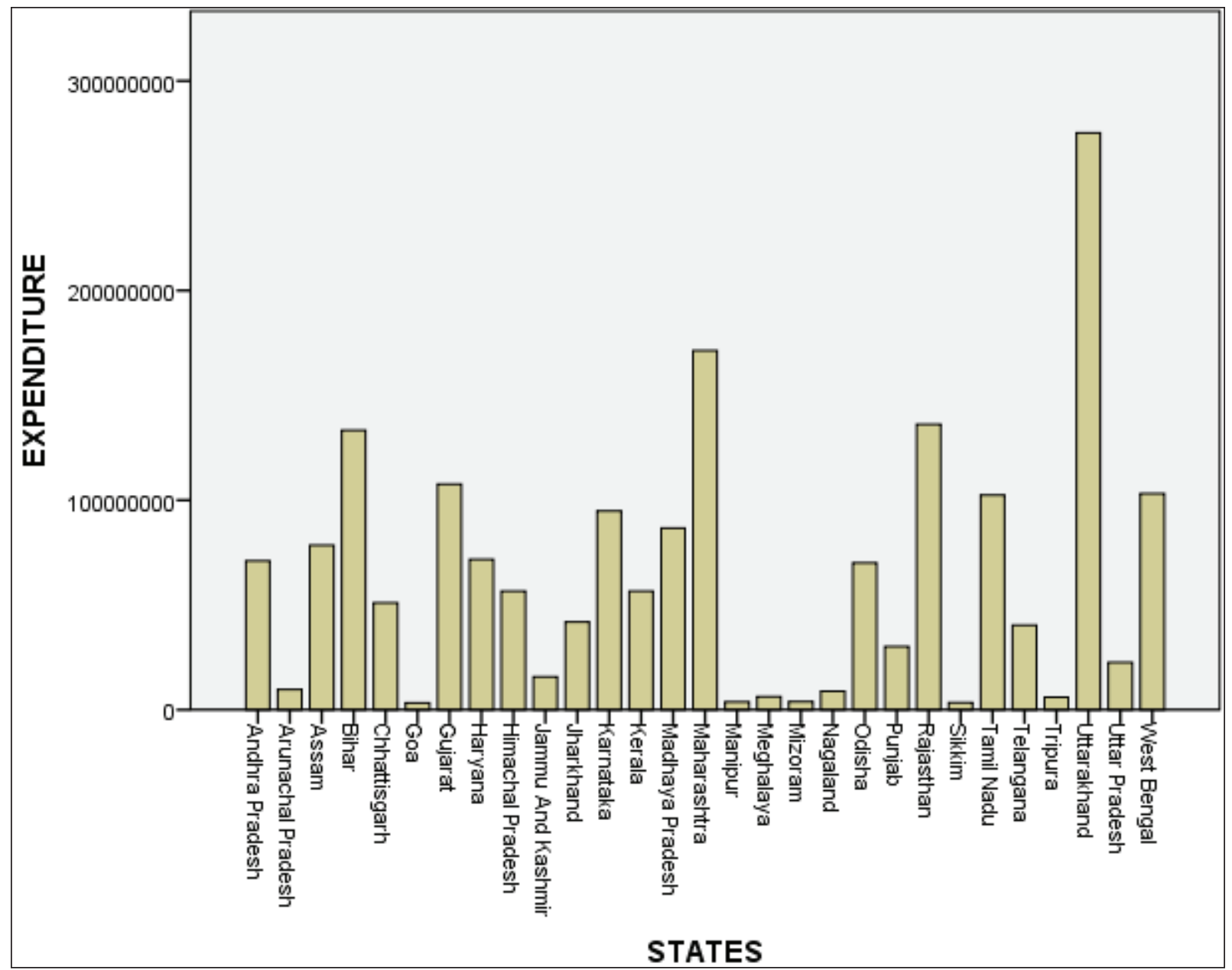

Source: Analysis of B.E. 2013-15.

Fig. 3: Total Revenue Expenditure of States on Education in 2015-16 


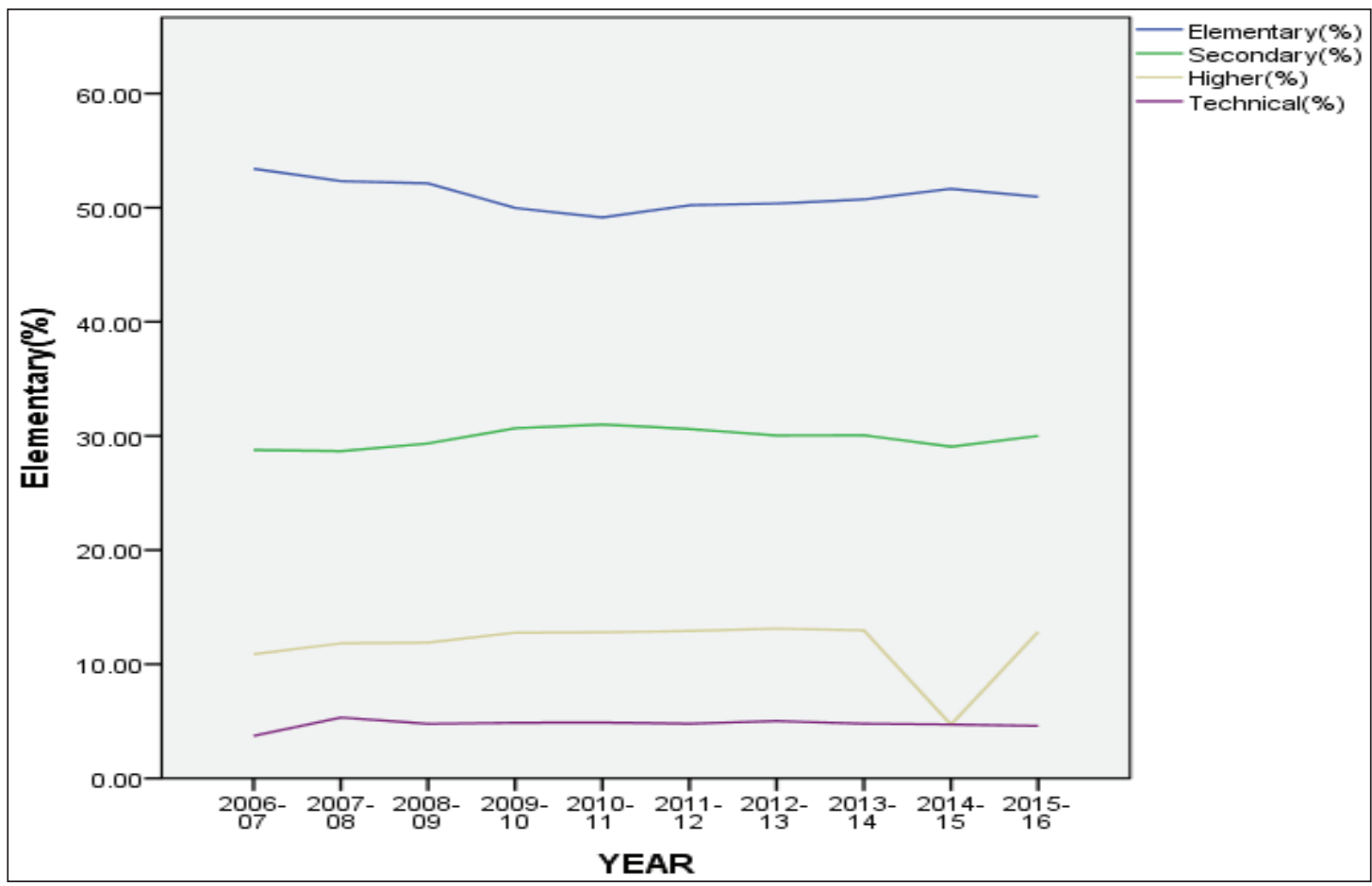

Source: Analysis of Budget Expenditure on Education, MHRD various issues.

Fig. 4: Sector-Wise Expenditure on Education as a percentage of Total Expenditure on Education

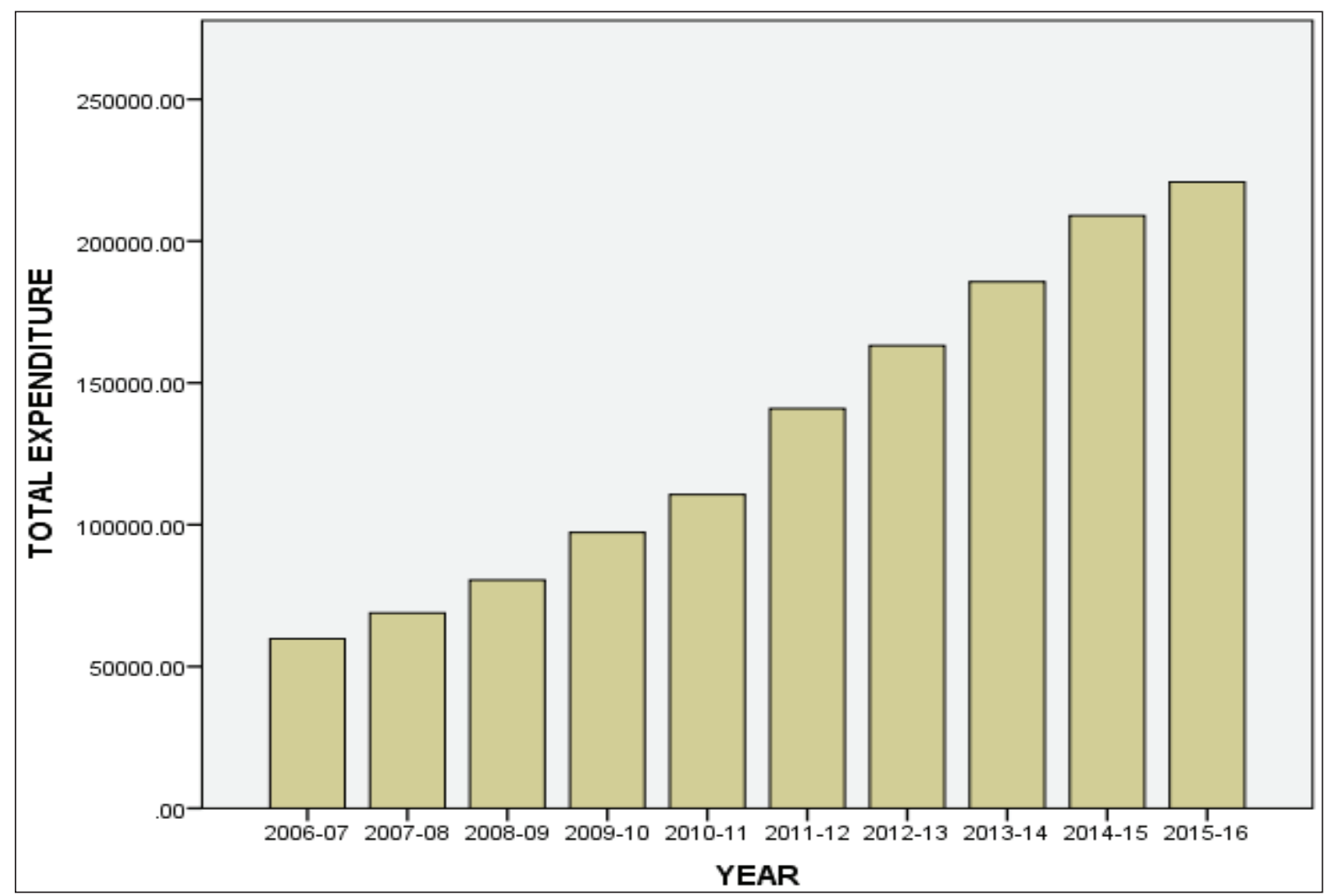

Source: Analysis of B.E., MHRD various issues.

Fig. 5: Total Expenditure on Elementary Education 
2014-15 and stood just 4.72 percent.

Technical education, although receiving smallest share of the total expenditure on education is steadily increasing from 3.72 percent in 2006-07 to 4.6 percentage in 2015-16.

The total expenditure on education consisting of expenditure by Centre and States has been rising in the absolute term since. However, this increase comes in different magnitude in terms of annual growth rate. The percentage increase in the expenditure from 2006-07 to 2007-08 is 15.27 percent whereas the percentage increase in the expenditure from $2014-15$ to $2015-16$ is only 5.67 percent.

The expenditure on secondary education is also increasing in the absolute terms since 2006-07. However, there is difference in terms of percentage increase in the expenditure from one year to another as evident from the fact that the percentage increase from $2006-07$ to $2007-08$ is 17.32 percent whereas the percentage increase from 2014-15 to 2015-16 is 10.53 percent.

The expenditure on university and higher education

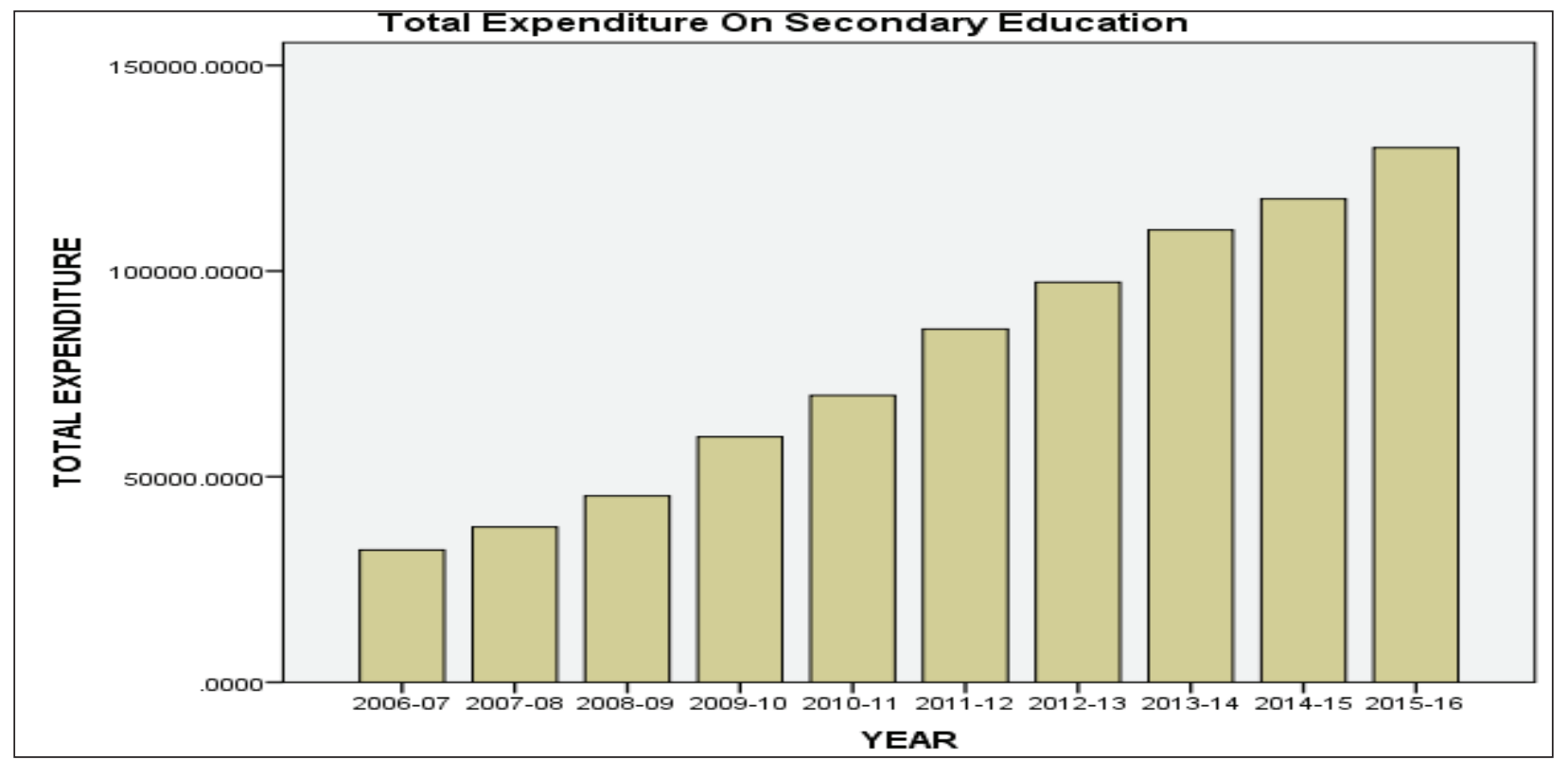

Source: Analysis of B.E., MHRD various issues.

Fig. 6: Total Expenditure on Secondary Education

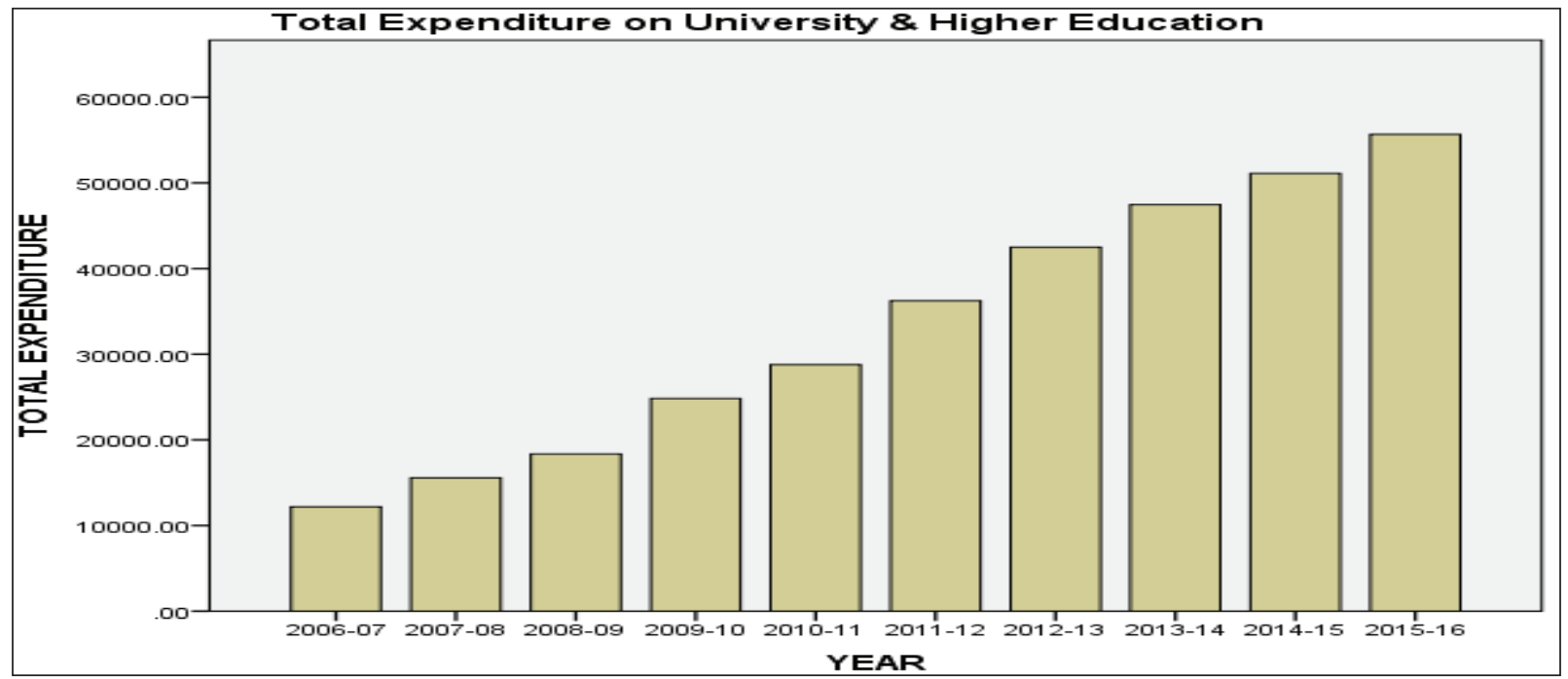

Source: Analysis of B.E., MHRD various issues.

Fig. 7: Total Expenditure on University and Higher Education 


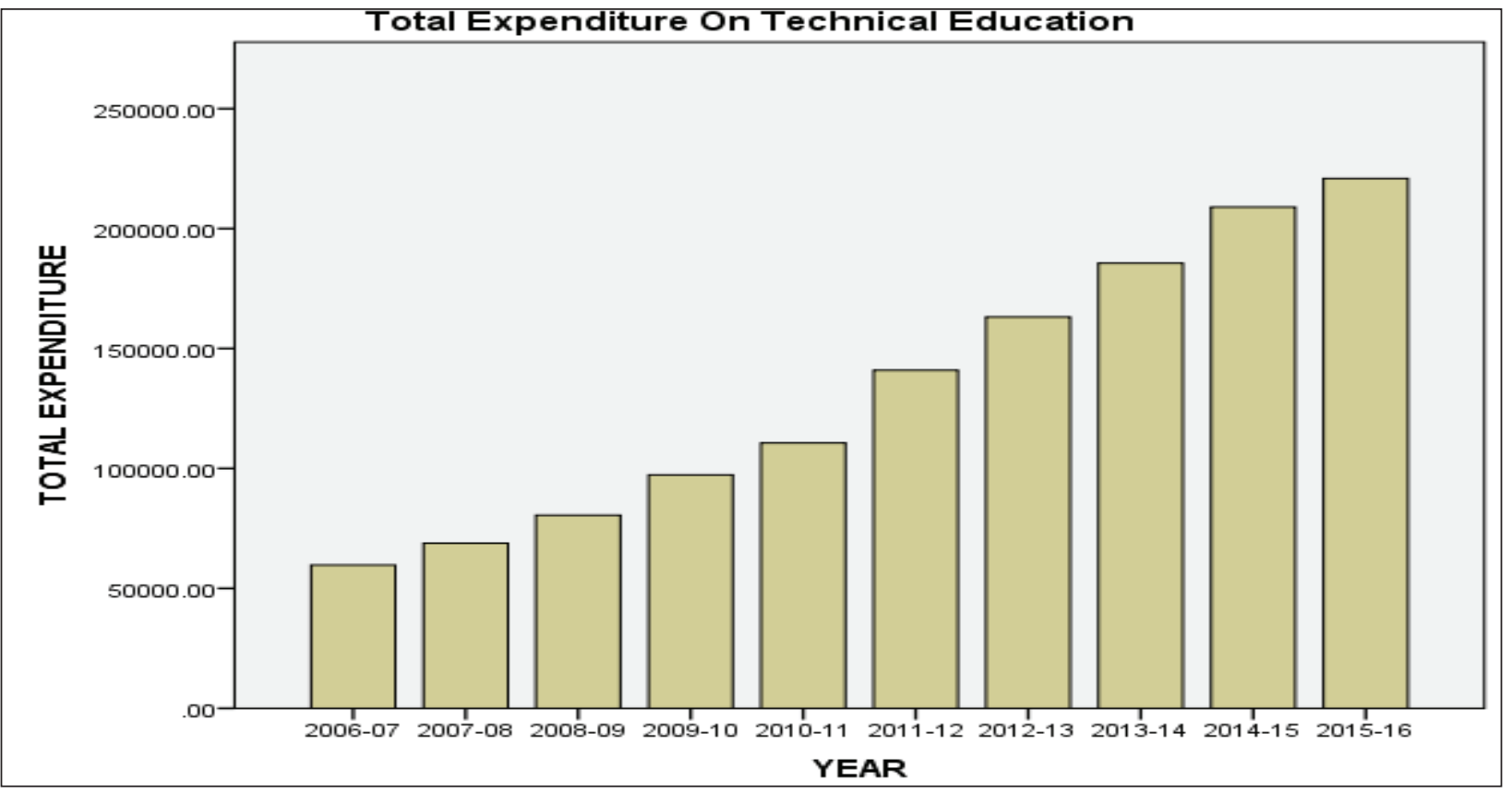

Source: Analysis of B.E., MHRD various issues.

Fig. 8: Total Expenditure on Technical Education

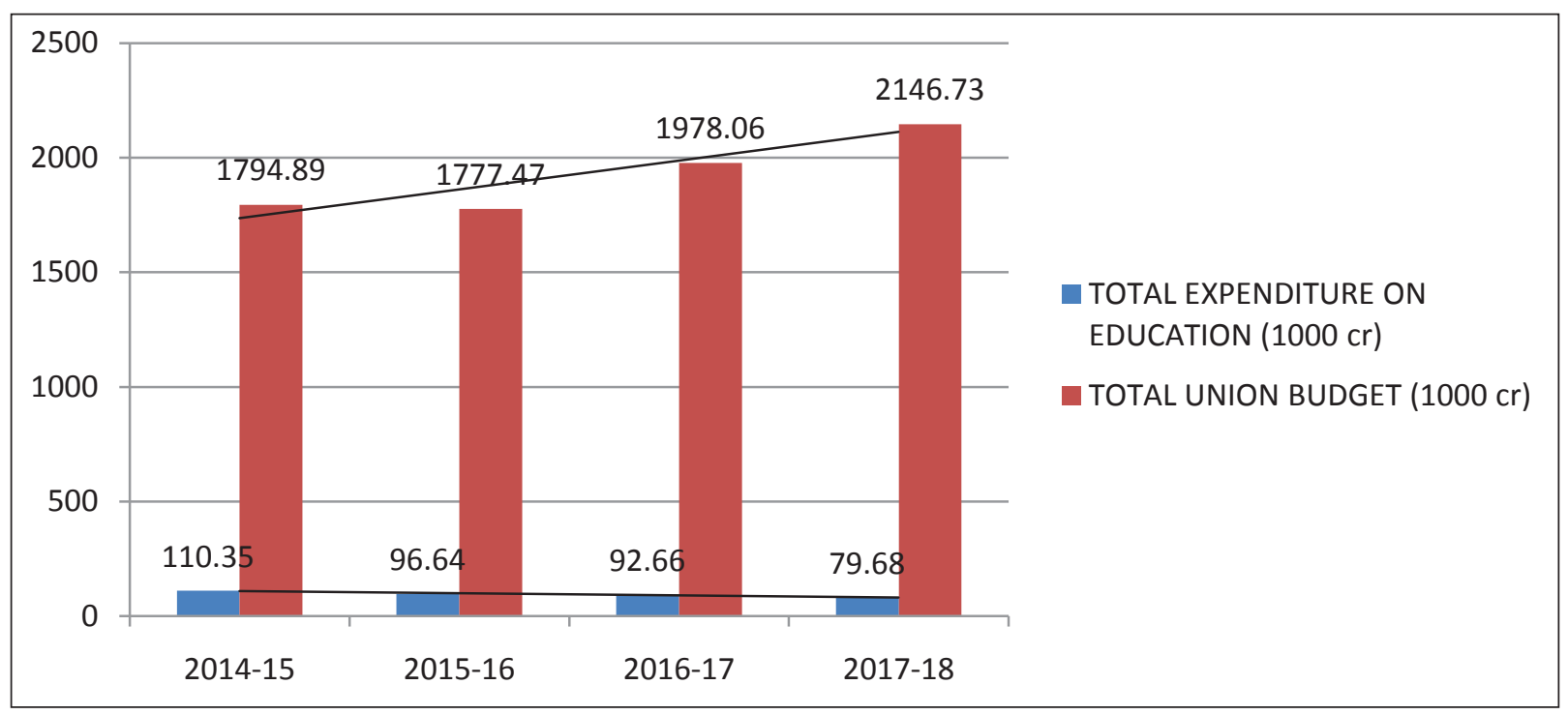

Source: Economic Survey 2017-18, Union Budget 2018-19

Fig. 9: Total Expenditure on Education and Total Union Budget

was 12176.71 thousand crores in the year 2006-07, it increased slowly over the decade and reached 55662.85 thousand crores in 2015-16 registering spectacular growth of 357.13 percent.

The expenditure on technical education was 4166850 crores in 2006-07 and it's been steadily increasing since then and has reached 19926840 crores in the year 2015-16.

The Fig. 9 shows that the total budget of the union government is continuously on rise with small decrease in 2015-16 from previous year whereas the total expenditure on education is falling continuously as quite evident from the negatively sloped trend line. On the one hand, the union budget increased from 1794.89 thousand crores in the year 2014- 15 to 2146.73 thousand crores in 2017-18. On the other, the expenditure on education fell from 110.35 thousand crores in 2014-15 to 79.68 
thousand crores in 2017-18 registering $27.79 \%$ decrease.

\section{CONCLUSION AND FINDINGS}

The total budgetary outlay by the union government is increasing since past few years, however, government spending on education has taken a back seat as it is quite evident from declining share of education expenditure in the total expenditure. This validates the assumption that government has been exercising retreat and withdrawing from social sector such as education, the phenomenon known as "shrinking state"..

Moreover, the share of elementary education in the total education has fallen from since 2006-07 whereas the share of expenditure on secondary and technical education has increased over the decade. The share of university and higher education has more and less remained stagnant with a deep fall in the year 2014-15 where it reached its lowest at 4.72 percent. This shows the shift in the government focus from elementary to secondary and technical education. Moreover, the total expenditure on education as a percentage of GDP has been oscillating between 3 to 4 percent over the years.

The foremost objective of the research paper was to find the link between the Gross Domestic Product (GDP) and expenditure on education in India. The findings from econometric analysis shows that the correlation between the GDP and expenditure on education is 0.42 but the results are not statistically significant (Appendix A.2.). Thus, we cannot reject the null hypothesis, that there is no correlation between expenditure on education and gross domestic product (GDP) in India.

The second objective of the study was to find the association between the State Gross Domestic Product and the expenditure on education by various states. The findings suggest that the correlation i.e., the degree of association between various states' expenditure on education as a percentage of SGDP and their respective GDP in 2015-16 is found out to be -0.513 and the results are statistically significant (Appendix A.4). Hence, it leads to the rejection of null hypothesis that there is no correlation between the SGDP and expenditure on education by the states. Therefore, it can be concluded that expenditure on education is negatively correlated with the SGDP and the strength of relationship is moderate. In other words, if a State's GDP is high it's spending on education as a percentage of SGDP is low and vice-versa. This variation from National to State level shows that the rich States are restraining from funding in education sector and have left the education sector in the hands of private institutions. On the other hand, poor States with low SGDP are spending higher proportion of their respective GDP on education.

\section{WAY FORWARD}

The proponents of human capital theory endorse the inevitable role played by education in the economic growth of the country as it leads to accumulation of human capital. Human capital is widely recognized as an important requirement for achieving sustained economic growth and rising incomes, particularly in developing country (world bank). It has been defined as the individual's stock of skills, traits and knowledge. The role of human capital in the development and growth of a nation is unquestionable. First, country's stock of skill is central to the potential for economic growth in highly competitive international environment. Second, the distribution of that human capital is a key determinant of income inequality, even more important with a high wag premium for skills. Third, the link between a person's human capital and their background is a fundamental determinant of social mobility and perpetuation of disadvantage. (Burgess). Education is one of the important determinants of productivity of human capital in the country. Like any other capital it can be increased through substantial investment which is known as education. Investment in education is an important lever of human capital in a country. Therefore, investment in education becomes important as it act as medium through which human capital and skill issues in a country can be addressed. Moreover, investment in education also leads to poverty reduction and economic development in a county which are crucial for the developing country like India.

However, in India the continuous fall in the total public spending on education highlights the likely withdrawal of the state. Additionally, it has important consequences for the whole country, as decrease in public expenditure in education is very likely to increase the privatisation in education 
which would result into further massification in education. Nevertheless, the beneficial effects of this massification would be contingent upon the quality education that it would entail, which in turn would require more regulatory role of the government as the absence of governance cannot be substitute for good governance.

\section{REFERENCES}

Allam, M. (n.d.). Financing Higher Education in the Cashless Economy : Challenges and Prospects. International Journal of Resent Scientific Research.

Andrew, S.R. 2007. Public Spending and outcomes: Does governance matter? Journal of Development Economics.

Burgess, S. (n.d.). Human Capital and Education: The State of the Art in the Economics of Education.

Davies. What works?: Evidence-based policy and practice in public services.

Gogoi, P.B. 2018. An Analysis of Trends, Growth and Changing Pattern of Public Expenditure on Higher Education in India. International Journal of Trend in Scientific
Research and Development.

Imana, D.K. 2007. The determinants of public education expenditures: An empirical analysis of changing patterns and growth of public expenditure on education in Kenya. Journal of Public Administration and Governance.

Khatei, P.K. 2018. An Analysis of Public Finance on Education Sector in India. Journal of Indian Taxation.

Linda Lobao, M.G. 2018. The shrinking state? Understanding the assault on the public sector. Cambridge Journal of Regions, Economy and Society, pp. 389-408.

Locatelli, R. 2018. Education as a public good and common good Re-framing the governance of education in a changing context. Education Research and Foresight.

Miron, J. 2010. The Negative Consequences of Government Expenditure.

Tilak, J. (n.d.). Financing Elementary Education in India.

Tilak, J. Financing of Education in India with a Focus on Elementary Education.

Usher, R. (n.d.). Experience, pedagogy, and social practices. 


\section{Appendix}

A.1. Scatter Plot of GDP and Expenditure on Education (as a \% of GDP)

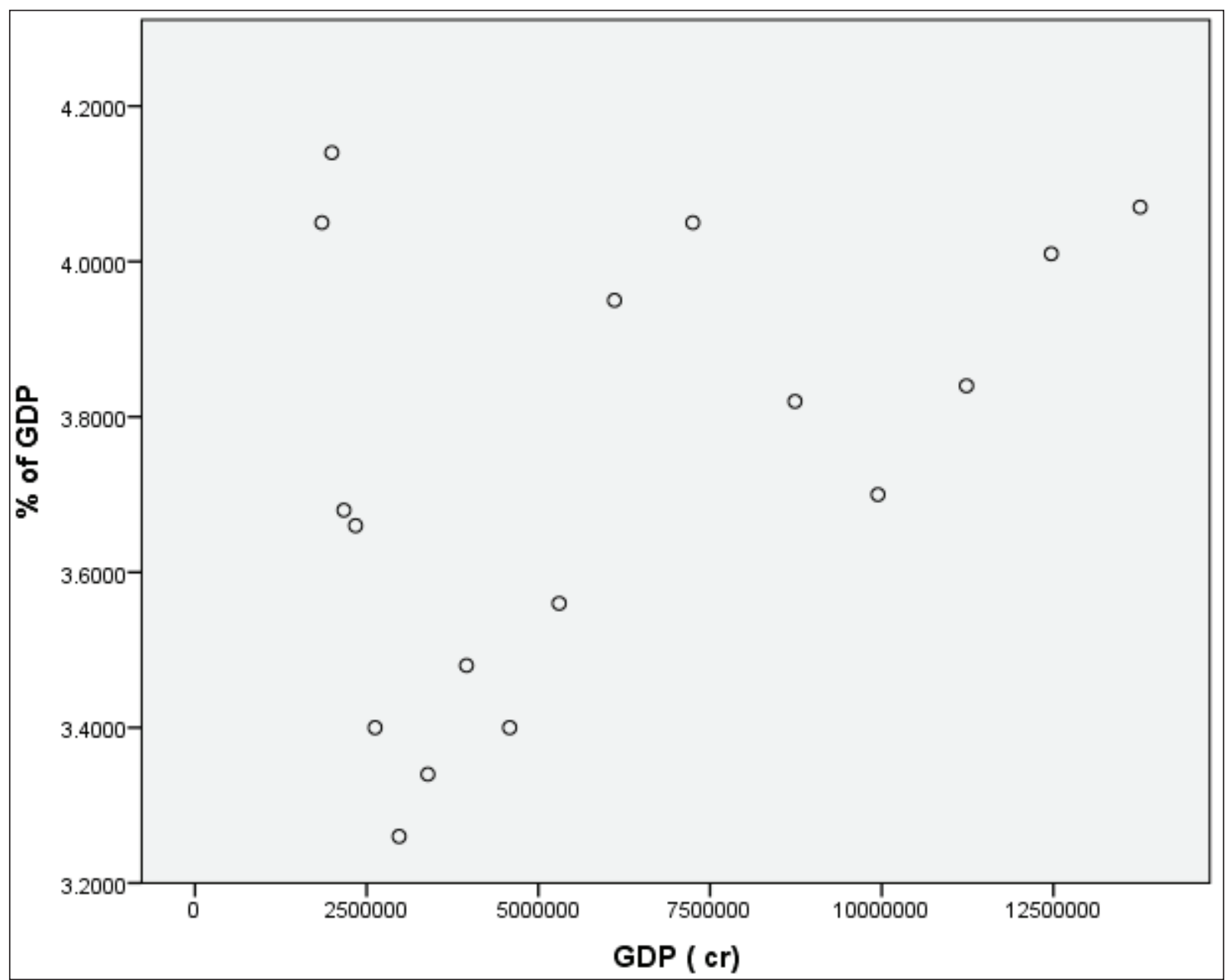

Source: Author

\section{A.2. Table: Correlations}

\begin{tabular}{llll}
\hline & & \% of GDP & GDP ( cr) \\
\hline \multirow{3}{*}{$\%$ of GDP } & Pearson Correlation & 1 & .424 \\
& Sig. (2-tailed) & & .090 \\
& $\mathrm{~N}$ & 17 & 17 \\
\hline \multirow{3}{*}{ GDP $(\mathrm{cr})$} & Pearson Correlation & .424 & 1 \\
& Sig. (2-tailed) & .090 & \\
& $\mathrm{~N}$ & 17 & 17 \\
\hline
\end{tabular}

Source: Author's Calculation. 


\section{A.3. Scatter Plot of Expenditure on Education and SGDP}

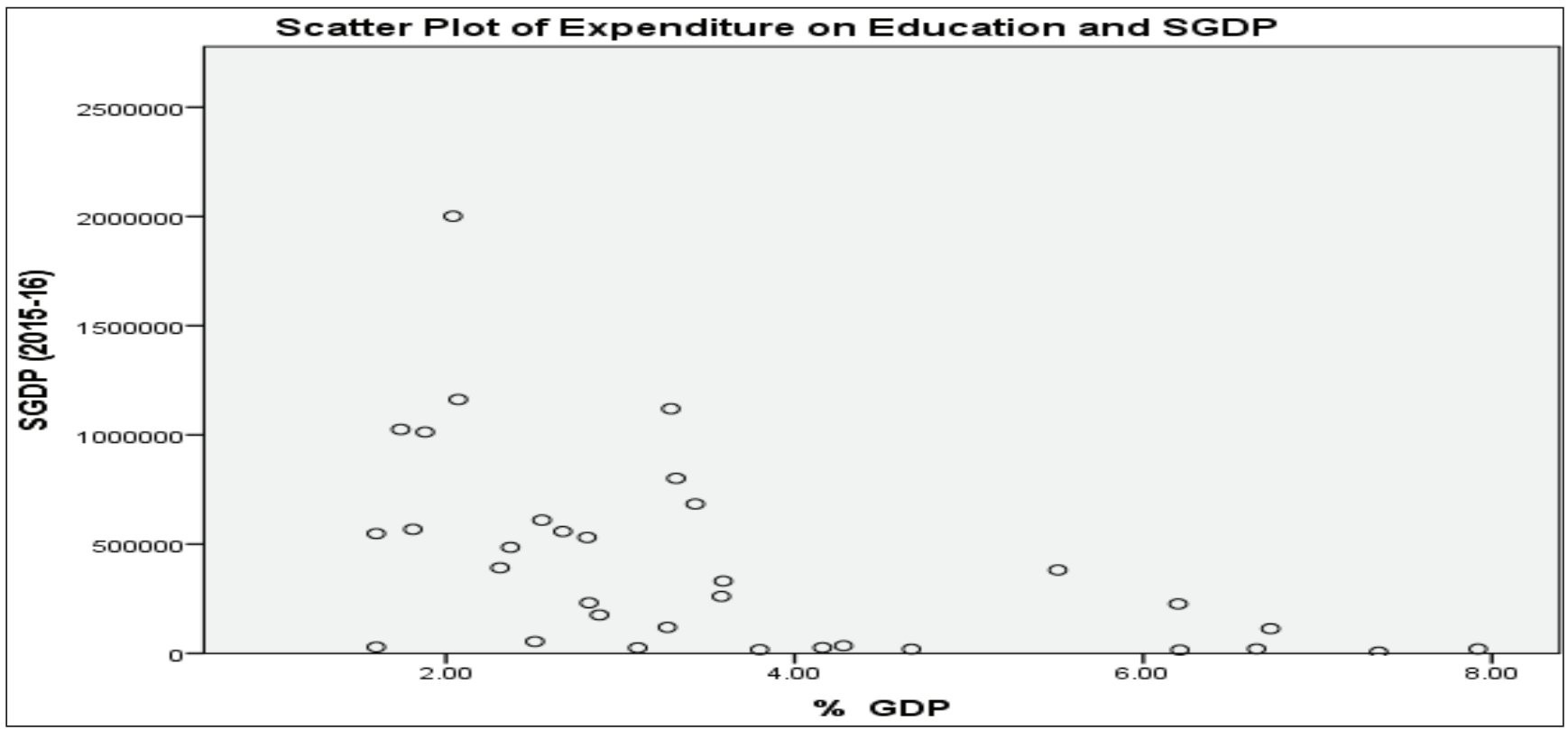

Source: Author

\section{A.4. Correlations}

\begin{tabular}{llll}
\hline & & \% GDP & SGDP (2015-16) \\
\hline \multirow{3}{*}{ \% GDP } & Pearson Correlation & 1 & $-.513^{* *}$ \\
& Sig. (2-tailed) & & .002 \\
& $\mathrm{~N}$ & 33 & 33 \\
\hline \multirow{3}{*}{ SGDP (2015-16) } & Pearson Correlation & $-.513^{* *}$ & 1 \\
& Sig. (2-tailed) & .002 & \\
& $\mathrm{~N}$ & 33 & 33 \\
\hline **. Correlation is significant at the 0.01 level (2-tailed). & & \\
\hline
\end{tabular}

Source: Author's Calculation. 
